\title{
Analysis of the structure-function relationship of the S-layer protein SbsC of Bacillus stearothermophilus ATCC 12980 by producing truncated forms
}

\author{
Marina Jarosch,, ${ }^{1}$ Eva M. Egelseer, ${ }^{1}$ Carina Huber, ${ }^{1}$ Dieter Moll, \\ Diethard Mattanovich, ${ }^{2}$ Uwe B. Sleytr ${ }^{1}$ and Margit Sára ${ }^{1}$
}

Author for correspondence: Margit Sára. Tel: +43147654 2208. Fax: +4314789112.

e-mail: sara@edv1.boku.ac.at

1 Centre for Ultrastructure Research and Ludwig Boltzmann-Institute for Molecular Nanotechnology, University of Agricultural Sciences, 1180 Vienna, Austria

2 Institute of Applied Microbiology, University of Agricultural Sciences, 1190 Vienna, Austria

\begin{abstract}
The mature surface layer (S-layer) protein SbsC of Bacillus stearothermophilus ATCC 12980 comprises amino acids 31-1099 and self-assembles into an oblique lattice type which functions as an adhesion site for a cell-associated highmolecular-mass exoamylase. To elucidate the structure-function relationship of distinct segments of SbsC, three $\mathbf{N}$ - and seven C-terminal truncations were produced in a heterologous expression system, isolated, purified and their properties compared with those of the recombinant mature S-layer protein rSbsC $_{\text {31-1099. }}$. With the various truncated forms it could be demonstrated that the $\mathrm{N}$-terminal part (aa 31-257) is responsible for anchoring the S-layer subunits via a distinct type of secondary cell wall polymer to the rigid cell wall layer, but this positively charged segment is not required for the self-assembly of SbsC, nor for generating the oblique lattice structure. If present, the $\mathbf{N}$-terminal part leads to the formation of in vitro double-layer self-assembly products. Affinity studies further showed that the $\mathbf{N}$-terminal part includes an exoamylase-binding site. Interestingly, the $\mathrm{N}$-terminal part carries two sequences of 6 and 7 aa (AKAALD and KAAYEAA) that were also identified on the amylase-binding protein AbpA of Streptococcus gordonii. In contrast to the self-assembling $\mathbf{N}$-terminal truncation rSbsC $_{258-1099}$, two further $\mathbf{N}$-terminal truncations ( rSbsC $_{343-1099}$, rSbsC $_{447-1099}$ ) and three C-terminal truncations (rSbsC $_{31-713}$, rSbsC $_{31-844}$, rSbsC $_{31-860}$ ) had lost the ability to self-assemble and stayed in the water-soluble state. Studies with the self-assembling C-terminal truncations rSbsC $\mathrm{C}_{31-880}, \mathrm{rSbsC}_{31-900}$ and rSbsC $_{31-920}$ revealed that the C-terminal 219 aa can be deleted without interfering with the self-assembly process, while the C-terminal 179 aa are not required for the formation of the oblique lattice structure.
\end{abstract}

Keywords: heterologous expression, self assembly, peptidoglycan, secondary cell wall polymer, exoamylase

\section{INTRODUCTION}

Crystalline bacterial cell surface layers (S-layers) are composed of identical protein or glycoprotein subunits with the ability to self-assemble into two-dimensional crystalline arrays, which completely cover the cell

Abbreviations: $\mathrm{GHCl}$, guanidine hydrochloride; GPC, gel-permeation chromatograpy; HMMA, high-molecular-mass exoamylase; SLH, S-layer homologous. surface of many bacteria and archaea during all stages of growth and division (Sára \& Sleytr, 2000; Sleytr \& Beveridge, 1999; Sleytr et al., 1999). S-layer lattices exhibit oblique, square or hexagonal symmetry with a centre-to-centre spacing of the morphological units of $3 \cdot 5-35 \mathrm{~nm}$. In bacteria, the S-layer subunits are linked to each other and to the underlying cell envelope layer by non-covalent interactions and can therefore be isolated from whole cells or cell wall fragments with hydrogenbond-breaking agents, by applying chelating agents or by changing the $\mathrm{pH}$. During removal of the disrupting 
agent, the S-layer subunits frequently reassemble in suspension, leading to self-assembly products which show the shape of flat sheets or open-ended cylinders and represent either monolayers or double layers (Sleytr et al., 1999).

The S-layer protein from Bacillus stearothermophilus ATCC 12980 assembles into an oblique lattice type (Egelseer et al., 1996). The gene encoding this S-layer protein $(s b s C)$ was sequenced and cloned, showing that the full-length SbsC consists of 1099 aa, possesses a 30 aa signal peptide and has a calculated isoelectric point (pI) of 5.73 (Jarosch et al., 2000). In the course of studies on the biological function, the oblique S-layer lattice was found to serve as an adhesion site for a cellassociated high-molecular-mass exoamylase (HMMA) which in the S-layer-deficient strain was bound to the peptidoglycan-containing rigid cell wall layer (Egelseer et al., 1996). By using the whole S-layer protein, proteolytic cleavage fragments, native peptidoglycananionic polymer complex and peptidoglycan for affinity studies, it became apparent that the N-terminal part of SbsC (aa 31-257) recognizes a distinct type of secondary cell wall polymer as the proper anchoring structure in the rigid cell wall layer (Egelseer et al., 1998). This secondary cell wall polymer is composed of tetrasaccharide repeating units that contain glucose, $\mathrm{N}$ acetylglucosamine and 2,3-dideoxy-2,3-diacetamido-Dmannuronic acid in the molar ratio of $1: 1: 2$ and the polymer chains are covalently linked to the peptidoglycan backbone (Schäffer et al., 1999). Due to the presence of uronic acids, this type of secondary cell wall polymer is strongly negatively charged and should be regarded as a member of the teichuronic acids (Archibald et al., 1993). Typical of protein domains capable of interacting with carbohydrates (Transue et al., 1997; Weis, 1997), the N-terminal part of the mature $\mathrm{Sbs} C$ has a high content of arginine, lysine and tyrosine. In contrast to the mature $\mathrm{SbsC}$, the $\mathrm{N}$-terminal part is positively charged, with a calculated pI of $9 \cdot 13$ (Jarosch et al., 2000). Moreover, the $\mathrm{N}$-terminal part of the mature SbsC shows $85 \%$ identity to the $\mathrm{N}$-terminal region of the mature SbsA, which assembles into a hexagonally ordered lattice and represents the S-layer protein of B. stearothermophilus PV72/p6 (Sára et al., 1996). According to a common functional principle, the $\mathrm{N}$-terminal part of the mature SbsA recognizes an identical type of secondary cell wall polymer as binding site in the rigid cell wall layer (Egelseer $e t$ al., 1998; Sára \& Sleytr, 2000).

In a previous study it was demonstrated that the S-layer protein isolated from $B$. stearothermophilus ATCC 12980 reassembles into small cylinders with a mean diameter of $100 \mathrm{~nm}$, but independent of the applied experimental conditions, the self-assembly products did not exhibit a regular lattice structure in negatively stained preparations (Egelseer et al., 1996, 1998). The absence of the oblique lattice structure was found to be due to the fact that B. stearothermophilus ATCC 12980 coexpresses a C-terminally truncated S-layer protein showing an apparent molecular mass of 60000 on SDS-
PAGE gels. This SbsC fragment, termed $\mathrm{P}_{60}$, was incorporated into the S-layer lattice on whole cells and led to the loss of its regular structure. The amount of $\mathrm{P}_{60}$ coexpressed with SbsC was strongly dependent on the growth conditions and on the growth stage of the cells. Moreover, the incorporation of $\mathrm{P}_{60}$ into the S-layer lattice on whole cells was linked to the release of HMMA into the culture fluid (Egelseer et al., 1996), suggesting that appropriate exoenzyme-binding sites in the S-layer lattice became blocked. Since HMMA recognized S-layer-carrying whole cells, S-layer-carrying cell wall fragments as well as self-assembly products as an adhesion site, it was concluded that the enzyme is not incorporated into the crystal lattice and does not participate in the self-assembly process, but binds to protein domains that are exposed on the outer S-layer surface. This was in clear contrast to $\mathrm{P}_{60}$, which showed no affinity to the outer surface of the S-layer lattice (Egelseer et al., 1996).

In order to investigate the self-assembly properties of SbsC in the absence of $\mathrm{P}_{60}$ and to elucidate the structure-function relationship of distinct segments of this S-layer protein, the PCR products encoding the mature $\mathrm{SbsC}$ and three $\mathrm{N}$ - and seven C-terminal truncations were cloned and expressed in Escherichia coli HMS174(DE3). After isolation and purification of the various $\mathrm{SbsC}$ truncations, their ability to selfassemble, to bind to the native peptidoglycan-anionic polymer complex as well as to peptidoglycan and to function as adhesion site for HMMA was investigated.

\section{METHODS}

Growth of B. stearothermophilus ATCC 12980, preparation of cell wall fragments and isolation of the native peptidoglycan-anionic polymer complex. B. stearothermophilus ATCC 12980 was grown in batch culture on SVIII medium or on complex medium under conditions given in previous studies (Egelseer et al., 1996, 1998). Preparation of cell wall fragments and extraction of the S-layer protein was performed as described by Egelseer et al. (1998). The native peptidoglycan-anionic polymer complex was purified according to the protocol established by Ries et al. (1997). For extraction of the secondary cell wall polymer, the native peptidoglycan-anionic polymer complex was treated with hydrofluoric acid ( $\mathrm{HF} ; 48 \%$ ) for $96 \mathrm{~h}$ at $4{ }^{\circ} \mathrm{C}$, which led to peptidoglycan of the A $1 \gamma$-chemotype (Egelseer et al., 1998).

Other strains, plasmid, culture conditions and DNA manipulations. E. coli TG1 was used for transformations with the plasmid pET3a. For expression, E. coli HMS174(DE3) was chosen as a host strain for derivatives of pET3a as described by Studier et al. (1990). E. coli was grown on Luria-Bertani medium (Gibco-BRL Life Technologies) or on modified M9ZB medium (Studier et al., 1990) at $37^{\circ} \mathrm{C}$. For selection of transformants harbouring pET3a, ampicillin was added to the medium to a final concentration of $50 \mu \mathrm{g} \mathrm{ml}^{-1}$. Chromosomal DNA of B. stearothermophilus ATCC 12980 was prepared by using Genomic Tips 100 (QIAGEN) according to the manufacturer's instructions. Digestion of PCR fragments with restriction endonucleases, separation of DNA fragments by agarose gel electrophoresis, ligation of DNA fragments and transformation procedures were performed as described by Sambrook et al. (1989). 
PCR amplification, plasmid construction, cloning and expression. Derived from the repeated amino acid sequences within SbsC and from sequence comparison with other S-layer proteins (Jarosch et al., 2000), various $\mathrm{N}$ - or C-terminal SbsC truncations $\quad\left(\mathrm{rSbsC}_{258-1099}, \quad \mathrm{rSbsC}_{343-1099}, \mathrm{rSbsC}_{447-1099}\right.$, $\mathrm{rSbsC}_{31-713}, \mathrm{rSbsC}_{31-844}, \mathrm{rSbsC}_{31-860}, \mathrm{rSbsC}_{31-880}, \mathrm{rSbsC}_{31-900}$, $\mathrm{rSbsC}_{31-920}$ and $\mathrm{rSbsC}_{31-930}$ ) were constructed by PCR amplification of the corresponding DNA fragments using the oligonucleotides listed in Table 1. For cloning, NdeI and Bam HI restriction sites were introduced during PCR at the $5^{\prime}$ and $3^{\prime}$ end, respectively. PCR amplification was performed under conditions given in a previous study (Jarosch et al., 2000). The PCR products encoding the mature SbsC $\left(\mathrm{rSbsC}_{31-1099}\right)$ or the various truncated $\mathrm{SbsC}$ forms were inserted into the corresponding restriction sites of pET3a and transformed into E. coli TG1 and E. coli HMS174(DE3). The plasmid stability test and expression were performed as described by Jarosch et al. (2000). Samples of cultures from $E$. coli HMS174(DE3) were taken $2-8 \mathrm{~h}$ after induction of expression. Preparation of biomass samples and SDS-PAGE were carried out as described by Laemmli (1970). Immunoblotting with polyclonal rabbit antiserum raised against the $\mathrm{S}$ layer protein of B. stearothermophilus ATCC 12980 and Nterminal sequencing was performed as described by Egelseer $e t$ al. (1996). Whole cells of E. coli HMS174(DE3) induced to express the various pET3a constructs were fixed, embedded in Spurr resin and subjected to ultrathin sectioning according to procedures given by Messner et al. (1984). Preparations were examined with a Philips CM 100 transmission electron microscope, operated at $80 \mathrm{kV}$ and equipped with a $30 \mu \mathrm{m}$ objective aperture.

Isolation and purification of $\mathrm{rSbsC}_{31-1099}$ and of the various $\mathrm{N}$ - or C-terminal SbsC truncations. Cultures of E. coli HMS174(DE3) cells induced to express the $s b s C$ gene or the various $s b s C$ derivatives were centrifuged $(6000 \mathrm{~g}, 10 \mathrm{~min}$, $4{ }^{\circ} \mathrm{C}$ ) and $1 \mathrm{~g}$ wet pellet of biomass was resuspended in $100 \mathrm{ml}$ $0 \cdot 1 \mathrm{M} \mathrm{CaCl}_{2}$ solution. After incubation on ice for $30 \mathrm{~min}$, the suspensions were centrifuged $\left(6000 \mathrm{~g}, 5 \mathrm{~min}, 4^{\circ} \mathrm{C}\right)$ and the pellets were resuspended in $100 \mathrm{ml} 0 \cdot 1 \mathrm{M}$ Tris/ $\mathrm{HCl}(\mathrm{pH} 8 \cdot 0)$ containing $1 \%(\mathrm{v} / \mathrm{v})$ glycerol, $10 \mathrm{mM}$ EDTA and $10 \mathrm{mg}$ lysozyme. The mixtures were heated in a water bath until $42{ }^{\circ} \mathrm{C}$ was reached and then incubated at $30^{\circ} \mathrm{C}$ for $15 \mathrm{~min}$. This was followed by the addition of $10 \mathrm{ml} 1 \%$ Triton X-100 in $50 \mathrm{mM}$ Tris $/ \mathrm{HCl}(\mathrm{pH} 7 \cdot 8)$ and by a further incubation step for $10 \mathrm{~min}$ at $20{ }^{\circ} \mathrm{C}$. After sonication of the suspensions (Branson Sonifier, $10 \times 10 \mathrm{~s}$ ), the soluble and insoluble fractions were separated by centrifugation $(20000 \mathrm{~g}, 30 \mathrm{~min}$, $4{ }^{\circ} \mathrm{C}$ ) and investigated by SDS-PAGE. The insoluble pellets were washed once with $1 \%$ Triton X-100 in $50 \mathrm{mM}$ Tris/ $\mathrm{HCl}$ (pH 7.8) and twice with $50 \mathrm{mM}$ Tris $/ \mathrm{HCl}(\mathrm{pH} 7 \cdot 8)$. The pellets were then resuspended in a fivefold volume of $5 \mathrm{M}$ guanidine hydrochloride $(\mathrm{GHCl})$ in $50 \mathrm{mM}$ Tris/ $\mathrm{HCl}$ buffer $(\mathrm{pH} 7 \cdot 2)$ and the suspensions were stirred for $20 \mathrm{~min}$ on ice. For removal of peptidoglycan fragments, the suspensions were centrifuged at $36000 \mathrm{~g}$ for $30 \mathrm{~min}$ at $4{ }^{\circ} \mathrm{C}$. The supernatant was diluted to a final $\mathrm{GHCl}$ concentration of $2 \mathrm{M}$ and $2 \mathrm{ml}$ of this solution was subjected to gel-permeation chromatography (GPC) using a Superdex 200 column (Pharmacia) for separation and $2 \mathrm{M} \mathrm{GHCl}$ in $50 \mathrm{mM}$ Tris/ $\mathrm{HCl}$ buffer $(\mathrm{pH} 7 \cdot 2)$ for elution. Fractions containing S-layer protein were pooled, dialysed against distilled water for at least $12 \mathrm{~h}$ at $4{ }^{\circ} \mathrm{C}$, frozen at $-20^{\circ} \mathrm{C}$ and lyophilized. The procedure for the isolation of the truncated $\mathrm{SbsC}$ forms from the soluble fraction (cytoplasm fraction of the E. coli cells) was as follows. After separation of the soluble and the insoluble fraction, the soluble S-layer proteins were precipitated with ammonium sulphate $(35-45 \%$ or $45-65 \%$ saturation). The resulting pellets were dissolved in $2 \mathrm{ml}$ distilled water and the solutions were dialysed against distilled water for at least $24 \mathrm{~h}$ at $4{ }^{\circ} \mathrm{C}$. Material which was still insoluble was removed by centrifugation $(36000 \mathrm{~g}$, $30 \mathrm{~min}, 4^{\circ} \mathrm{C}$ ) and the clear supernatants were applied onto a Superdex 200 column using $150 \mathrm{mM} \mathrm{NaCl}$ in $50 \mathrm{mM}$ Tris/ $\mathrm{HCl}$ buffer $(\mathrm{pH} \mathrm{7 \cdot 2)}$ for elution. Fractions containing S-layer protein were pooled, dialysed against distilled water for at least $24 \mathrm{~h}$ at $4{ }^{\circ} \mathrm{C}$ and lyophilized.

Investigation of the self-assembly properties of rSbsC $_{31-1099}$ and of the various $\mathrm{N}$ - or C-terminal SbsC truncations. To evaluate the self-assembly properties, $1 \mathrm{mg}$ of the purified and lyophilized S-layer proteins was dissolved per $\mathrm{ml} 2 \mathrm{M} \mathrm{GHCl}$ in $50 \mathrm{mM}$ Tris/HCl buffer $(\mathrm{pH} \mathrm{7 \cdot 2})$. The solutions were dialysed against distilled water, $10 \mathrm{mM} \mathrm{CaCl}$ or $10 \mathrm{mM} \mathrm{KCl}$ for at least $24 \mathrm{~h}$ at $20^{\circ} \mathrm{C}$. The suspensions were negatively stained and prepared for ultrathin sectioning according to procedures described by Messner et al. (1984). Labelling of self-assembly products formed by $\mathrm{rSbs}_{31-1099}$ with polycationized ferritin as a positively charged topographical marker was carried out as described in a previous study (Messner et al., 1986).

Isolation of HMMA from the S-layer deficient strain, and affinity studies. Extraction of HMMA from cell wall fragments of the S-layer-deficient strain of B. stearothermophilus ATCC 12980 with $4 \mathrm{M} \mathrm{GHCl}$ in $50 \mathrm{mM}$ Tris/ $\mathrm{HCl}$ buffer ( $\mathrm{pH} 7 \cdot 2$ ) was performed as described by Egelseer et al. (1996). After centrifugation of the suspension at $36000 \mathrm{~g}$ for $10 \mathrm{~min}$ at $4^{\circ} \mathrm{C}$, the clear supernatant was diluted with $50 \mathrm{mM}$ Tris $/ \mathrm{HCl}$ buffer to a final $\mathrm{GHCl}$ concentration of $2 \mathrm{M}$ and the solution was subjected to GPC using a Sephacryl S-200 column for separation. Fractions containing HMMA were pooled, dialysed against $50 \mathrm{mM}$ Tris/ $\mathrm{HCl}$ buffer $(\mathrm{pH} \mathrm{7 \cdot 2)}$ for $24 \mathrm{~h}$ at $4{ }^{\circ} \mathrm{C}$ and the protein content of the dialysed solution was adjusted to $100 \mu \mathrm{g}$ per $\mathrm{ml}$ buffer. The purity of HMMA was checked by SDS-PAGE and the amylolytic activity was visualized in situ on SDS-gels by the method of Lacks \& Springhorn (1980). To perform the binding assay, $1 \mathrm{mg}$ lyophilized self-assembly products consisting of $\mathrm{rSbsC}_{31-1099}$, rSbsC $_{31-880}$ or $\mathrm{rSbsC}_{258-1099}$ were dissolved in $1 \mathrm{ml} 2 \mathrm{M} \mathrm{GHCl}$ in $50 \mathrm{mM}$ Tris/ $\mathrm{HCl}$ buffer, and the solutions were dialysed for $18 \mathrm{~h}$ at $20^{\circ} \mathrm{C}$ against $50 \mathrm{mM}$ Tris $/ \mathrm{HCl}$ buffer. After the addition of $100 \mu \mathrm{l}$ HMMA solution, the suspensions were incubated for $20 \mathrm{~min}$ at $20^{\circ} \mathrm{C}$, centrifuged at $36000 \mathrm{~g}$ for $10 \mathrm{~min}$ at $4{ }^{\circ} \mathrm{C}$ and the pellets were washed twice with buffer. The pellets and the supernatants were collected and analysed by SDS-PAGE. For comparison, self-assembly products formed by the S-layer protein from Bacillus sphaericus CCM 2177 were used (Ilk et al., 1999). The affinity of the HMMA to the native peptidoglycan-anionic polymer complex and to peptidoglycan devoid of the secondary cell wall polymer from B. stearothermophilus ATCC 12980, B. stearothermophilus PV72/p2 (Sára et al., 1996) and B. sphaericus CCM 2177 (Ilk et al., 1999) was also investigated.

Investigation of the affinity of $\mathrm{rSbsC}_{31-1099}$ and of the various $\mathrm{N}$ - or C-terminal SbsC truncations to the native peptidoglycan-anionic polymer complex as well as to peptidoglycan. For affinity studies, $1 \mathrm{mg}$ lyophilized $\mathrm{rSbsC}_{31-1099}$ and of the self-asssembling SbsC truncations was dissolved in $1 \mathrm{ml} 2 \mathrm{M} \mathrm{GHCl}$ in $50 \mathrm{mM}$ Tris/HCl buffer ( $\mathrm{pH} 7 \cdot 2$ ) and either $1 \mathrm{mg}$ lyophilized native peptidoglycananionic polymer complex or $1 \mathrm{mg}$ peptidoglycan (HFextracted peptidoglycan-anionic polymer complex) was added. The suspensions were then stirred for $15 \mathrm{~min}$ at $20^{\circ} \mathrm{C}$. After dialysis against distilled water for at least $24 \mathrm{~h}$ at $4^{\circ} \mathrm{C}$, the suspensions were negatively stained and prepared for ultrathin sectioning. To investigate the binding properties of 


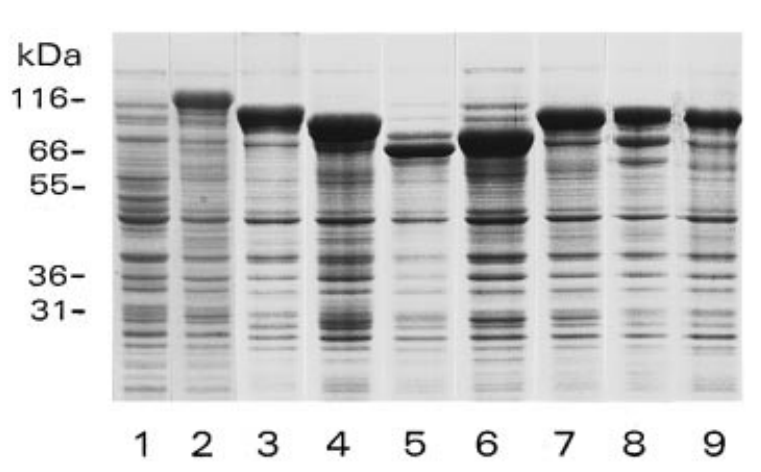

Fig. 1. SDS-PAGE patterns of whole-cell extracts of $E$. coli HMS174(DE3) harbouring either the pET3a plasmid (lane 1) or the various $\mathrm{pET3a}$ gene constructs encoding the mature S-layer protein ( $\mathrm{rSbsC}_{31-1099,}$ lane 2) or the truncated $\mathrm{SbsC}$ forms (rSbsC $_{258-1099}$, lane 3; rSbsC $_{343-1099}$ lane 4; rSbsC $_{447-1099}$ lane 5; $\mathrm{rSbsC}_{31-713}$, lane 6; $\mathrm{rSbsC}_{31-844}$, lane 7; $\mathrm{rSbsC}_{31-860}$, lane 8; $\mathrm{rSbsC}_{31-880}$, lane 9). The molecular masses are indicated on the left. the soluble truncated S-layer proteins, $1 \mathrm{mg}$ of the lyophilized material was dissolved in $1 \mathrm{ml} 50 \mathrm{mM}$ Tris/HCl buffer ( $\mathrm{pH} 7 \cdot 2$ ) and $1 \mathrm{mg}$ native peptidoglycan-anionic polymer complex or peptidoglycan was added. The suspensions were incubated for $30 \mathrm{~min}$ at $20{ }^{\circ} \mathrm{C}$ and centrifuged at $36000 \mathrm{~g}$ for $20 \mathrm{~min}$ at $4^{\circ} \mathrm{C}$. Subsequently, the pellets and the supernatants were analysed by SDS-PAGE.

DNA sequencing. $\mathrm{PCR}$ products encoding the mature $\mathrm{SbsC}$ or the various truncated $\mathrm{Sbs} C$ forms were sequenced as described elsewhere (Jarosch et al., 2000).

\section{RESULTS}

Expression of the sbsC gene and of the various $s b s C$ derivatives in $E$. coli HMS174(DE3), and isolation and purification of $\mathrm{rSbsC}_{31-1099}$ and the various $\mathrm{SbsC}$ forms

The PCR products encoding the mature $\mathrm{SbsC}$ and the various $\mathrm{N}$ - or $\mathrm{C}$-terminal SbsC truncations (Table 1) were cloned and expressed in E. coli HMS174(DE3).

Table 1. Survey of the properties of the recombinant mature SbsC and the various truncated SbsC forms

\begin{tabular}{|c|c|c|c|c|c|}
\hline $\begin{array}{l}\text { rSbsC } \\
\text { form }\end{array}$ & Primer* sequence $\left(5^{\prime}\right.$ to $\left.3^{\prime}\right)$ & $\begin{array}{l}\text { Theoretical } \\
\text { mol. mass } \\
\text { (Da) }\end{array}$ & $\begin{array}{l}\text { Apparent } \\
\text { mol. mass } \\
\text { on SDS- } \\
\text { PAGE }(\mathrm{kDa})\end{array}$ & $\mathrm{pI} \dagger$ & $\begin{array}{l}\text { N-terminal } \\
\text { sequence } \neq\end{array}$ \\
\hline $\mathrm{rSbsC}_{31-1099}$ & $\begin{array}{l}\text { CGCGGATCCCATATG/GCAACGGACGTGGCGAC } \\
\text { CGCGGATCC/TTACGATGCTGATTTTGTACCAATTTG reverse }\end{array}$ & 112471 & 122 & $5 \cdot 40$ & ATDVA \\
\hline $\mathrm{rSbsC}_{258-1099}$ & $\begin{array}{l}\text { CGCGGATCCCATATG/GCAGCATTGACGCCGAAGG } \\
\text { CGCGGATCC/TTACGATGCTGATTTTGTACCAATTTG reverse }\end{array}$ & 87259 & 91 & $4 \cdot 89$ & AALTP \\
\hline $\mathrm{rSbsC}_{343-1099}$ & $\begin{array}{l}\text { CGCGGATCCCATATG/GCTGGTAAAGAATTTGAAACTAGC } \\
\text { CGCGGATCC/TTACGATGCTGATTTTGTACCAATTTG reverse }\end{array}$ & 78271 & 82 & $4 \cdot 80$ & AGKEF \\
\hline $\mathrm{rSbsC}_{447-1099}$ & $\begin{array}{l}\text { CGCGGATCCCATATG/GCAGAAGTTAGTGAATTAAAATTAAC } \\
\text { CGCGGATCC/TTACGATGCTGATTTTGTACCAATTTG reverse }\end{array}$ & 67091 & 66 & $4 \cdot 71$ & AEVSE \\
\hline $\mathrm{rSbsC}_{31-713}$ & $\begin{array}{l}\text { CGCGGATCCCATATG/GCAACGGACGTGGCGAC } \\
\text { CGCGGATCC/TTATGCATTAACGATTACACCATTTGTATC } \\
\text { reverse }\end{array}$ & 73137 & 73 & $6 \cdot 55$ & ATDVA \\
\hline $\mathrm{rSbsC}_{31-844}$ & $\begin{array}{l}\text { CGCGGATCCCATATG/GCAACGGACGTGGCGAC } \\
\text { CGCGGATCC/TTAAGCATCATCTTTTAAGTTATCAAC reverse }\end{array}$ & 86624 & 90 & $5 \cdot 41$ & ATDVA \\
\hline $\mathrm{rSbsC}_{31-860}$ & $\begin{array}{l}\text { CGCGGATCCCATATG/GCAACGGACGTGGCGAC } \\
\text { CGCGGATCC/TTATGTTAATGTTACTGTACCTGCTTTC reverse }\end{array}$ & 88152 & 91 & $5 \cdot 62$ & ATDVA \\
\hline $\mathrm{rSbsC}_{31-880}$ & $\begin{array}{l}\text { CGCGGATCCCATATG/GCAACGGACGTGGCGAC } \\
\text { CGCGGATCC/TTAAGCAGGAGCTTTAACTGTGATTG reverse }\end{array}$ & 90231 & 93 & $5 \cdot 62$ & ATDVA \\
\hline $\mathrm{rSbsC}_{31-900}$ & $\begin{array}{l}\text { CGCGGATCCCATATG/GCAACGGACGTGGCGAC } \\
\text { CGCGGATCC/TTATACACCAGTTACACCTGGCAC reverse }\end{array}$ & 92113 & 96 & $5 \cdot 42$ & ATDVA \\
\hline $\mathrm{rSbsC}_{31-920}$ & $\begin{array}{l}\text { CGCGGATCCCATATG/GCAACGGACGTGGCGAC } \\
\text { CGCGGATCC/TTAAGCATAATATAATTTGTGACCAGATTTG } \\
\text { reverse }\end{array}$ & 94353 & 98 & $6 \cdot 09$ & ATDVA \\
\hline $\mathrm{rSbsC}_{31-930}$ & $\begin{array}{l}\text { CGCGGATCCCATATG/GCAACGGACGTGGCGAC } \\
\text { CGCGGATCC/TTAAGCTGGCGCAGGTACTG reverse }\end{array}$ & 95276 & 100 & $5 \cdot 74$ & ATDVA \\
\hline
\end{tabular}

* Oligonucleotide primers used for amplification in PCR.

†Calculated isoelectric point.

$\ddagger$ Determined experimentally. 

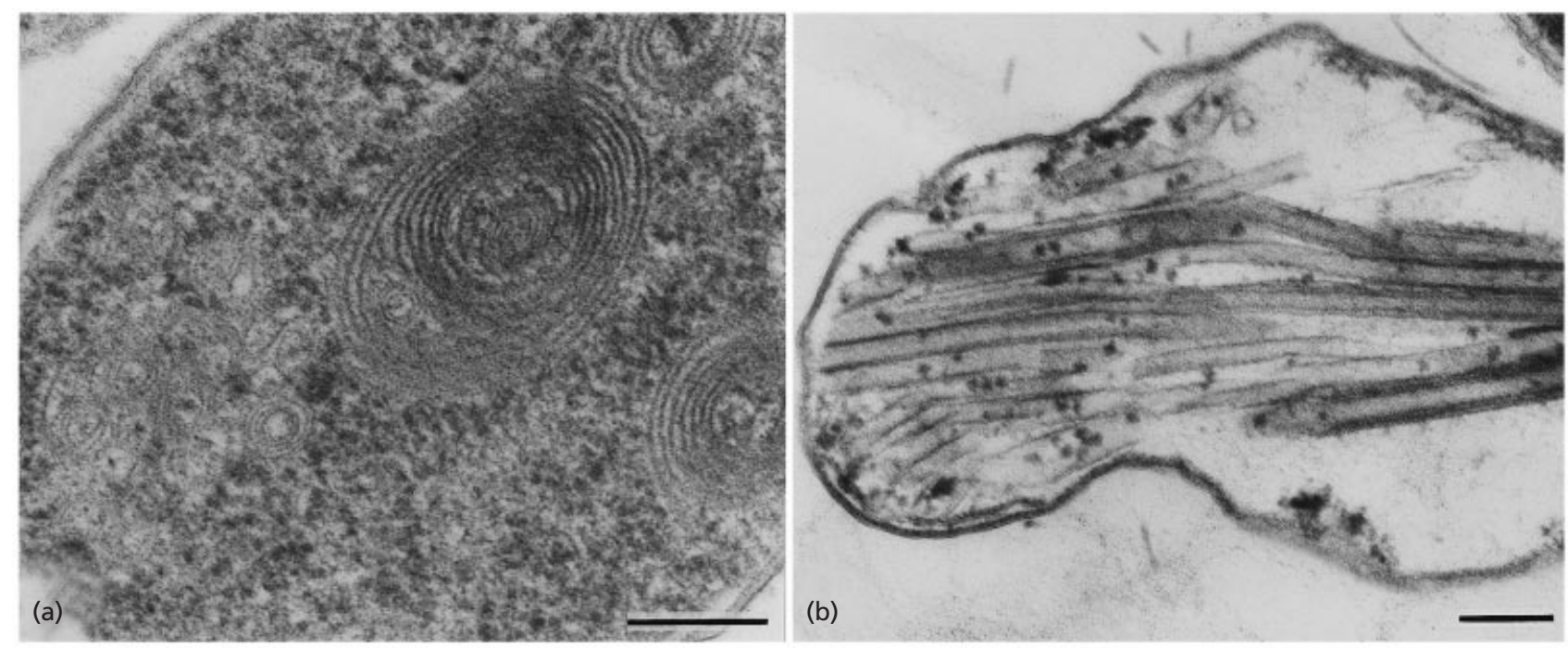

Fig. 2. Electron micrographs of ultrathin sections of $E$. coli HMS174(DE3) demonstrating the presence of self-assembly products consisting of (a) SSbsC $_{31-1099}$ or (b) rSbsC $_{258-1099}$ in the cytoplasm of the host cells. Bars, $200 \mathrm{~nm}$.

After induction of expression by the addition of IPTG, biomass samples were harvested at various times and analysed by SDS-PAGE and ultrathin sectioning. In comparison to E. coli HMS174(DE3) carrying pET3a (Fig. 1, lane 1), an additional high-molecular-mass protein band was observed on SDS-PAGE gels in samples from E. coli HMS174(DE3) cells induced to express the $s b s C$ gene or the various $s b s C$ derivatives (Fig. 1, lanes 2-9). In such samples, the apparent molecular mass of the additional protein band corresponded approximately to the calculated molecular mass of the mature $\mathrm{SbsC}$ or of the respective $\mathrm{N}$ - or Cterminal truncation (Table 1). On immunoblots, a strong cross-reaction was observed between these protein bands and the polyclonal rabbit antiserum raised against the S-layer protein of B. stearothermophilus ATCC 12980 (data not shown). The identification of the additional protein bands as the mature SbsC or as the $\mathrm{N}$ or C-terminal SbsC truncations was accomplished by $\mathrm{N}$-terminal sequencing (Table 1).

To investigate whether $\mathrm{rSbsC}_{31-1099}$ and the various truncated $\mathrm{Sbs} C$ forms assembled in the cytoplasm of the host cells, whole cells of E. coli HMS174(DE3) carrying the constructs were fixed and embedded and the ultrathin sections were examined by electron microscopy. In longitudinal ultrathin sections of cells producing $\mathrm{rSbsC}_{31-1099}$, sheet-like structures were visible which were arranged in a parallel fashion at high density, but cross-sections showed that these sheet-like structures were organized as closely packed spirally wound sheets (Fig. 2a). Similar structures were observed in cells synthesizing the $\mathrm{C}$-terminal truncations $\mathrm{rSbsC}_{31-880}, \mathrm{rSbsC}_{31-900}, \mathrm{rSbsC}_{31-920}$ and $\mathrm{rSbsC}_{31-930}$. In longitudinal sections of whole cells producing the $\mathrm{N}$ terminal truncation $\mathrm{rSbsC}_{258-1099}$, monolayer cylinders with a diameter of about $50 \mathrm{~nm}$ were visible (Fig. 2b). A similar observation was made for the N-terminal truncation $\mathrm{rSbsC}_{343-1099}$. No structures indicating the formation of self-assembly products were observed in ultrathin sections of cells producing the truncated forms $\mathrm{rSbsC}_{447-1099}, \mathrm{rSbsC}_{31-713}, \mathrm{rSbsC}_{31-844}$ and $\mathrm{rSbsC}_{31-860}$ (not shown).

As revealed by electron microscopy, self-assembly in the cytoplasm of the host cells was a characteristic of $\mathrm{rSbsC}_{31-1099}$, of the $\mathrm{N}$-terminal truncations $\mathrm{rSbsC}_{258-1099}$ and $\mathrm{rSbsC}_{343-1099}$, and of the $\mathrm{C}$-terminal truncations $\mathrm{rSbsC}_{31-880}, \mathrm{rSbsC}_{31-900}, \mathrm{rSbsC}_{31-920}$ and $\mathrm{rSbsC}_{31-930}$. These findings were basically confirmed by data from SDS-PAGE, since with the exception of $\mathrm{rSbsC}_{343-1099}$, the mature recombinant $\mathrm{S}$-layer protein and all other truncated $\mathrm{SbsC}$ forms that assembled in the cytoplasm of the host cells had accumulated in the insoluble fraction of the lysed E. coli cells. On the other hand, the truncated forms $\mathrm{rSbsC}_{343-1099}, \mathrm{rSbsC}_{447-1099}, \mathrm{rSbsC}_{31-713}$, $\mathrm{rSbsC}_{31-844}$ and $\mathrm{rSbsC}_{31-860}$ were exclusively detected in the soluble fraction of the host cells, and they could be separated from other soluble proteins by ammonium sulphate precipitation and purification by GPC. All truncated $\mathrm{Sbs} C$ forms that were enriched in the insoluble fraction were extracted with $5 \mathrm{M} \mathrm{GHCl}$ and subjected to GPC. Each purified SbsC form migrated as a single protein band with the expected molecular mass on SDSgels (e.g. Fig. 3d, inset; Table 1).

\section{Self-assembly products formed by $\mathrm{rSbsC}_{31-1099}$ and by the various $\mathrm{N}$ - or $\mathrm{C}$-terminal SbsC truncations}

To investigate the self-assembly properties, the purified $\mathrm{S}$-layer proteins were disintegrated in $\mathrm{GHCl}$, which was subsequently removed by dialysis against distilled water or solutions of monovalent or bivalent cations. As shown by negative staining, $\mathrm{rSbs}_{31-1099}$ reassembled 

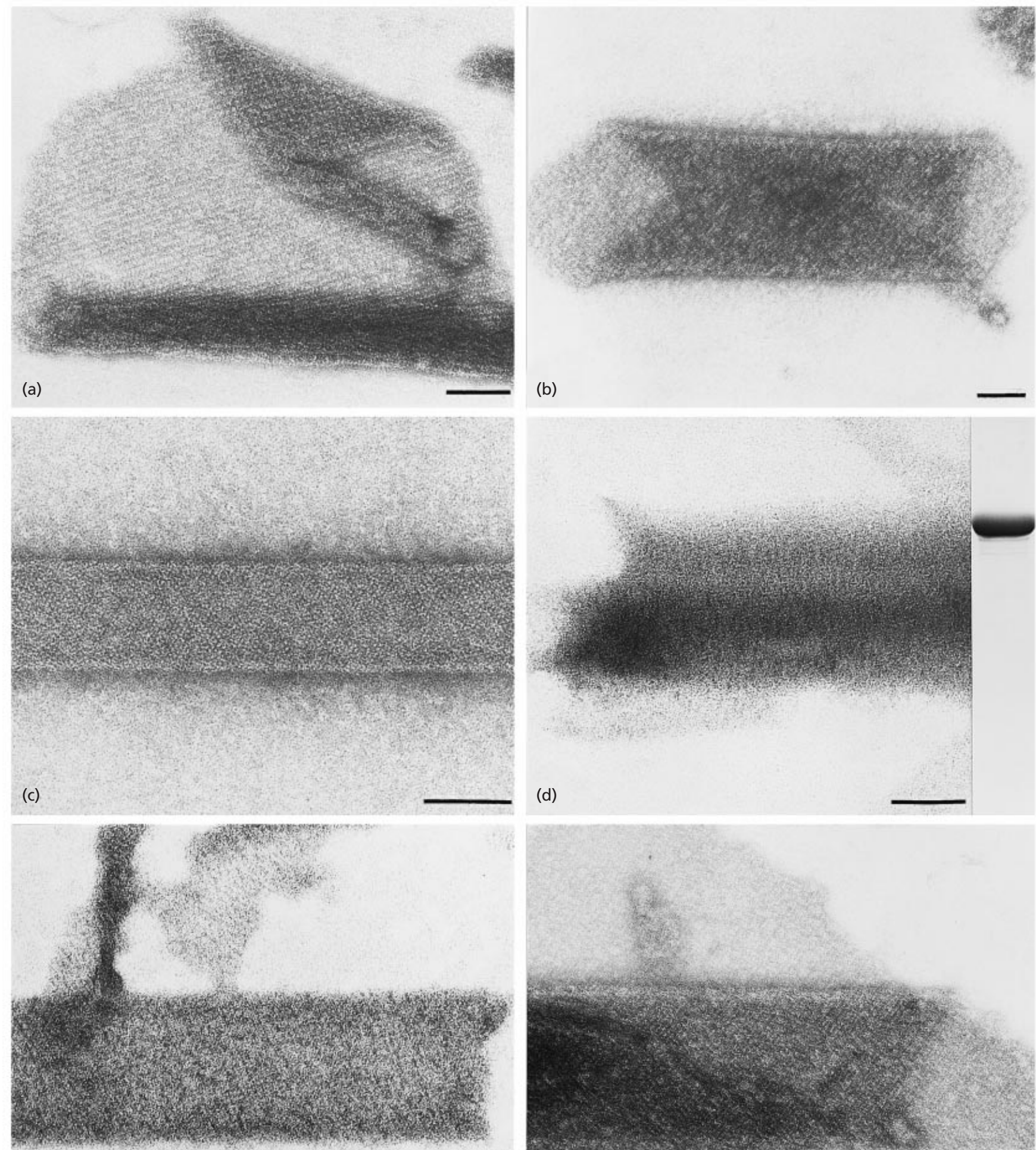

(e)

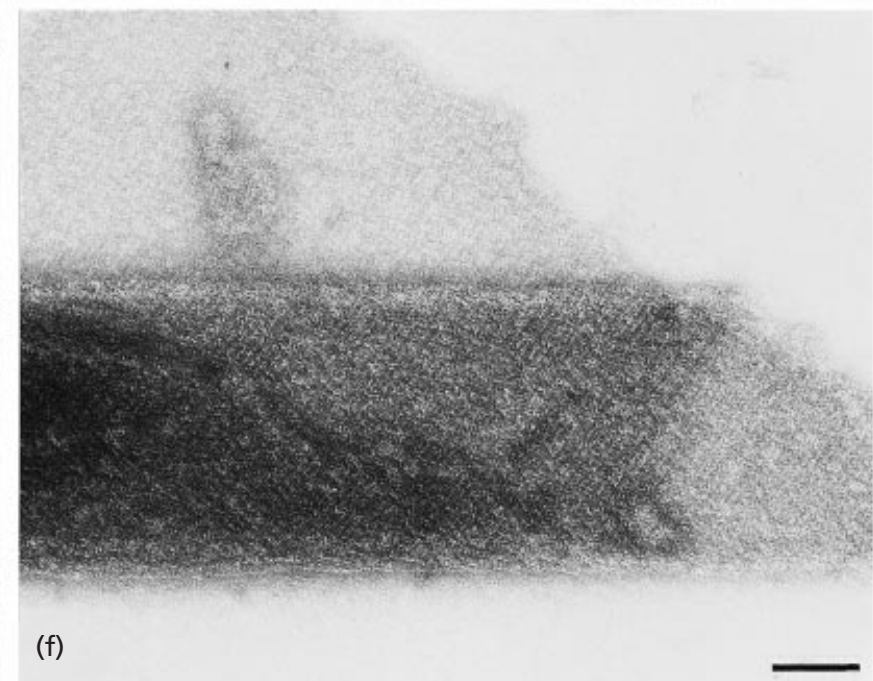

Fig. 3. Electron micrographs of negatively stained preparations of self-assembly products formed by $\mathrm{rSbs}_{3} \mathrm{C}_{3109}$ and by the various truncated SbsC forms. In the case of self-assembly products formed by rSbs $_{31-1099}$, double-layer sheets (a) and double-layer cylinders (b) are shown. The $\mathrm{N}$-terminal truncation $\mathrm{rSbsC}_{258-1099}$ reassembled exclusively into monolayer cylinders (c) exhibiting an oblique lattice structure. Self-assembly products formed by the C-terminal truncation $\mathrm{rSbs}_{31-880}$ did not show a regular lattice structure (d). A faint lattice structure was observed on self-assembly products consisting of rSbsC $_{31-900}$ (e), while self-assembly products formed by rSbsC $_{31-920}$ clearly exhibited the oblique lattice structure (f). Bars, $100 \mathrm{~nm}$. Inset in (d): SDS-PAGE pattern of purified $\mathrm{rSbsC}_{31-880}$. 


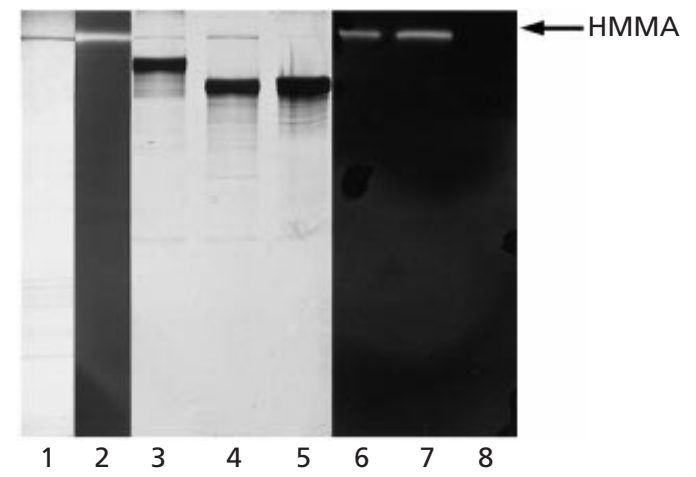

Fig. 4. SDS-PAGE patterns demonstrating the purity (lane 1) and activity (lane 2) of HMMA and its affinity to self-assembly products consisting of $\mathrm{rSbsC}_{31-1099}$ (lanes 3 and 6), $\mathrm{rSbsC}_{31-880}$ (lanes 4 and 7) and rSbsC $_{258-1099}$ (lanes 5 and 8). Lanes 1 and $3-5$, silver staining; lanes $2,6-8$, in situ detection of amylolytic activity. The position of the HMMA is indicated.

into double-layer sheets (Fig. 3a) and into open-ended monolayer and double-layer cylinders. The diameter of the monolayer cylinders was in the range of $70-100 \mathrm{~nm}$, while the double-layer cylinders (Fig. 3b) were generally larger, with a diameter of $220-280 \mathrm{~nm}$. As determined by computer image reconstruction of negatively stained preparations, the self-assembly products clearly exhibited the oblique (p2) lattice structure with the lattice constants of $a=11.6 \mathrm{~nm}, b=7.2 \mathrm{~nm}$ and $\gamma=$ $81^{\circ}$ (D. Pum, personal communication). Labelling with polycationized ferritin revealed that the self-assembly products did not bind this positively charged topographical marker (not shown). Since some of the selfassembly products were monolayers, it became apparent that neither the outer nor the inner S-layer surface has a net negative charge. In contrast to $\mathrm{rSbsC}_{31-1099}$, the $\mathrm{N}$ terminal truncation $\mathrm{rSbsC}_{258-1099}$ reassembled exclusively into monolayer cylinders with a maximum diameter of $130 \mathrm{~nm}$, which in negatively stained preparations exhibited an oblique lattice structure very weak in contrast (Fig. 3c).

As observed with the C-terminal truncations $\mathrm{rSbsC}_{31-880}, \mathrm{rSbsC}_{31-900}$ and $\mathrm{rSbsC}_{31-920}$, the length in this part of the sequence had a significant influence on the formation of the oblique lattice structure. The Cterminal truncation $\mathrm{rSbsC}_{31-880}$ reassembled into flat sheets or open-ended cylinders and the self-assembly process was as quantitative as that of $\mathrm{rSbsC}_{31-1099}$, since no S-layer protein could be detected in the supernatant after the removal of self-assembled material by centrifugation. In contrast to $\mathrm{rSbsC}_{31-1099}$, self-assembly products formed by $\mathrm{rSbs}_{31-880}$ did not exhibit a regular lattice structure (Fig. 3d). Self-assembly products consisting of $\mathrm{rSbsC}_{31-900}$ (Fig. 3e), $\mathrm{rSbsC}_{31-920}$ (Fig. 3f) or $\mathrm{rSbsC}_{31-930}$ (not shown) had a comparable shape, but differences were observed in the quality of the oblique lattice structure. For example, self-assembly products formed by $\mathrm{rSbsC}_{31-900}$ exhibited only a diffuse lattice structure in negatively stained preparations (Fig. 3e), while self-assembly products consisting of $\mathrm{rSbsC}_{31-920}$ (Fig. 3f) or $\mathrm{rSbsC}_{31-930}$ clearly showed the oblique lattice structure. Considering the water solublity of $\mathrm{rSbs}_{31-860}$ and the formation of first self-assembly products by $\mathrm{rSbsC}_{31-880}$, an elongation by 20 aa was sufficient to establish the contact sites necessary for subunit-tosubunit interactions. Based on the results obtained with $\mathrm{rSbsC}_{31-880}$ and $\mathrm{rSbsC}_{31-920}$, only 40 additional aa in the $\mathrm{C}$-terminal part were required to completely restore the oblique lattice structure (Fig. 3e, f).

\section{Affinity studies with HMMA}

In addition to self-assembly products formed by $\mathrm{rSbsC}_{31-1099}$, those consisting of $\mathrm{rSbsC}_{258-1099}$ or $\mathrm{rSbsC}_{31-880}$, which represented either the shortest $\mathrm{N}$ - or the shortest C-terminal truncation capable of selfassembly, were used for affinity studies with HMMA. As shown by SDS-PAGE, the exoenzyme (Fig. 4, lanes 1 and 2) could bind to self-assembly products formed by $\mathrm{rSbsC}_{31-1099}$ (Fig. 4, lanes 3 and 6) or $\mathrm{rSbsC}_{31-880}$ (Fig. 4, lanes 4 and 7), but not to those consisting of $\mathrm{rSbs}_{258-1099}$ (Fig. 4, lanes 5 and 8), which indicated that the $\mathrm{N}$ terminal part of $\mathrm{Sbs} C$ must comprise the binding region for HMMA. Actually, two sequences of 6 and 7 aa (AKAALD and KAAYEAA), which are located between aa 223-228 and 254-260 in the N-terminal part of SbsC, were previously identified in the amylase-binding protein AbpA of Streptococcus gordonii (Rogers et al., 1998). Further affinity studies revealed that HMMA recognized the native peptidoglycan-anionic polymer complex from B. stearothermophilus ATCC 12980, as well as pure peptidoglycan of the A1 $\gamma$-chemotype from which the secondary cell wall polymer had been extracted, as binding site. Moreover, HMMA could bind to the native peptidoglycan-anionic polymer complex of B. stearothermophilus PV72/p2, which possesses the same peptidoglycan chemotype (A1 $\gamma)$, but reveals a different type of secondary cell wall polymer (Sára \& Sleytr, 2000). In contrast, the exoenzyme did not bind to native peptidoglycan-anionic polymer complex or to peptidoglycan from B. sphaericus CCM 2177, which has a different peptidoglycan chemotype $(\mathrm{A} 4 \alpha)$ (Ilk et al., 1999) as well as a different type of secondary cell wall polymer than B. stearothermophilus ATCC 12980 (Egelseer et al., 1998). Furthermore, the exoenzyme did not bind to self-assembly products formed by the S-layer protein from B. sphaericus CCM 2177 (not shown).

\section{Affinity of $\mathrm{rSbsC}_{31-1099}$ and of the various $\mathrm{N}$ - or C-terminal SbsC truncations to the native peptidoglycan-anionic polymer complex and to peptidoglycan}

For affinity studies, $\mathrm{rSbsC}_{31-1099}$ and all self-assembling SbsC truncations were dissolved in $2 \mathrm{M} \mathrm{GHCl}$ and incubated with the native peptidoglycan-anionic poly- 


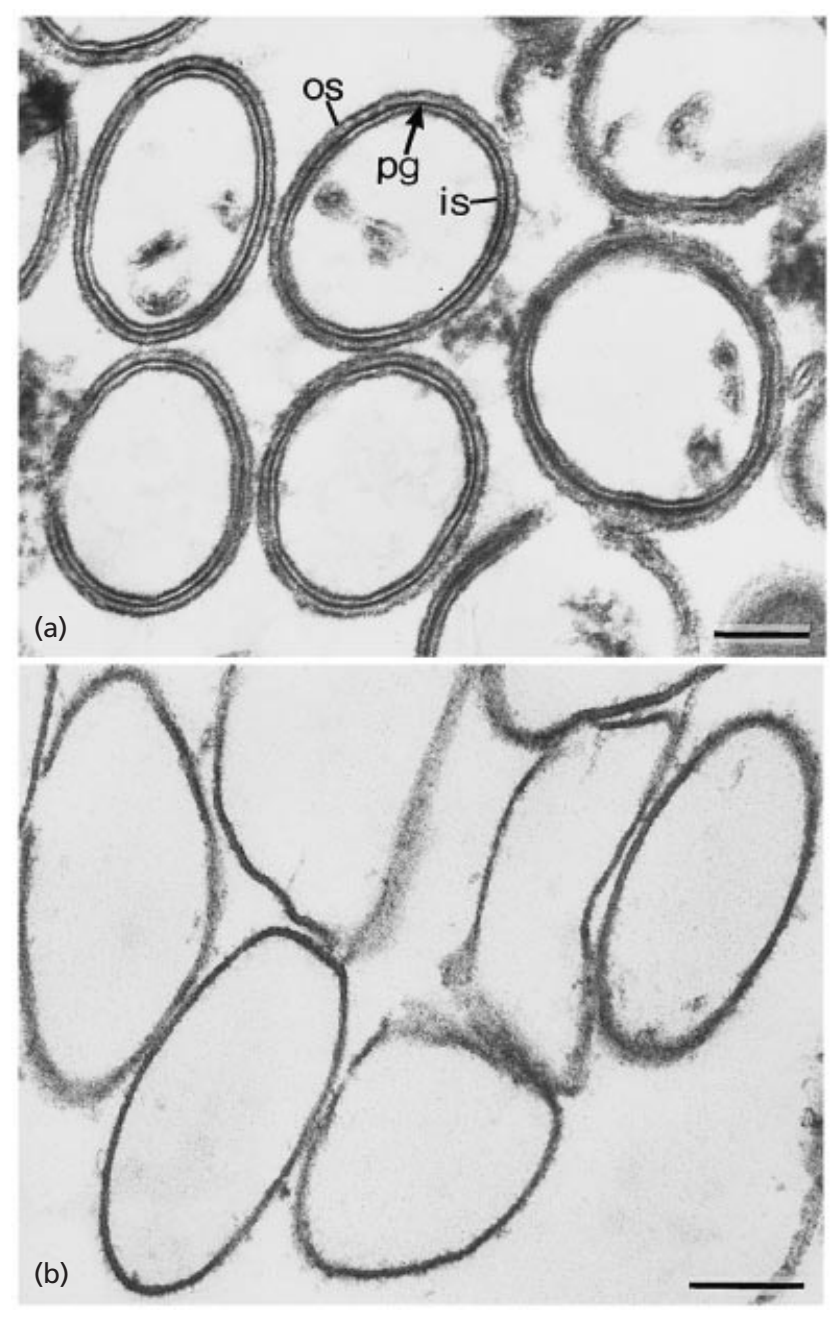

Fig. 5. Electron micrographs of ultrathin sections demonstrating the ability of the C-terminal truncation SSbsC $_{31-900}$ to bind to (a) native peptidoglycan-anionic polymer complex but not (b) peptidoglycan. os, outer S-layer; pg, peptidoglycancontaining layer; is, inner S-layer. Bars, $200 \mathrm{~nm}$.

mer complex (and in some selected examples with peptidoglycan). After removal of $\mathrm{GHCl}$ by dialysis, the pellets obtained by centrifugation were prepared for ultrathin sectioning. It could be demonstrated that $\mathrm{rSbsC}_{31-1099}$ and all self-assembling C-terminal truncations $\left(\mathrm{rSbsC}_{31-880}, \mathrm{rSbsC}_{31-900}, \mathrm{rSbsC}_{31-920}\right.$, $\mathrm{rSbsC}_{31-930}$ ) recognized the native peptidoglycananionic polymer complex, but not peptidoglycan as binding site (Fig. 5a, b; shown only for $\mathrm{Sbs}_{31-900}$ ). If the native peptidoglycan-anionic polymer complex was used as matrix for recrystallization, a complete outer and inner S-layer was formed (Fig. 5a). In contrast to the C-terminal self-assembling truncations, the $\mathrm{N}$-terminal truncation $\mathrm{rSbsC}_{258-1099}$ did not bind to the native peptidoglycan-anionic polymer complex and reassembled into the characteristic monolayer cylinders (not shown). The affinities of the water-soluble N- or Cterminal truncations to the native peptidoglycan-

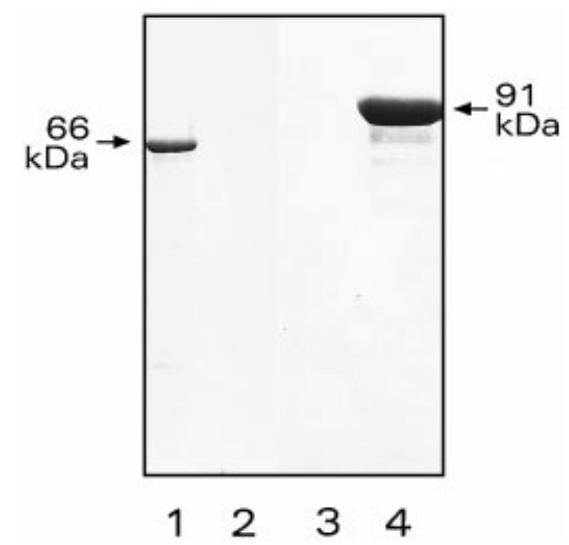

Fig. 6. SDS-PAGE patterns demonstrating the results of the affinity studies of selected water soluble $\mathrm{N}$ - or C-terminal truncations ( $\mathrm{SSbsC}_{447-1099}$ and $\left.\mathrm{rSbsC}_{31-844}\right)$ to the native peptidoglycan-anionic polymer complex. After centrifugation of the suspensions, the whole amount of $\mathrm{rSbsC}_{447-1099}$ remained in the clear supernatant (lane 1) and no protein could be detected in the pellet (lane 2). In contrast, no $\mathrm{rSbsC}_{31-844}$ was detected in the supernatant (lane 3), and the whole amount was concentrated in the pellet consisting of the native peptidoglycan-anionic polymer complex (lane 4). The molecular masses are indicated.

anionic polymer complex and to peptidoglycan were the same as those of the self-assembling N- or C-terminal SbsC truncations. As demonstrated by SDS-PAGE, neither $\mathrm{rSbsC}_{343-1099}$ (not shown) nor $\mathrm{rSbsC}_{447-1099}$ (Fig. 6 , lanes 1 and 2) showed affinity to the native peptidoglycan-anionic polymer complex, whereas $\mathrm{rSbsC}_{31-713}$, (not shown), $\mathrm{rSbsC}_{31-844}$ (Fig. 6, lanes 3 and 4) and $\mathrm{rSbsC}_{31-860}$ (not shown) recognized them as binding site. As expected, the water soluble C-terminal truncations did not bind to peptidoglycan (not shown).

\section{DISCUSSION}

Up to now, only a little information has been available on the self-assembly and cell wall-binding properties of truncated S-layer proteins and there exist no data as to which parts of the S-layer proteins could be responsible for exoenzyme binding. In the case of Aeromonas bydrophila (Thomas et al., 1992), a Gram-negative organism exhibiting a square S-layer lattice, a mutant producing a C-terminally truncated S-layer protein was isolated. The molecular mass of the truncated form comprising the protease-resistant $\mathrm{N}$-terminal domain was $39 \mathrm{kDa}$ instead of $52 \mathrm{kDa}$ for the mature S-layer protein. Although the truncated form was exported via the periplasm, it could not be anchored to the outer membrane nor could it self-assemble into the square lattice structure (Trust, 1993). A truncated form of the Slayer protein SlpA from Thermus thermophilus which was devoid of the S-layer-homologous (SLH) motifs located in the $\mathrm{N}$-terminal part resulted in a protein unable to attach to the cell surface and to assemble into the hexagonally ordered lattice type (Olabarría et al., 
1996). In contrast, the $\mathrm{N}$-terminal parts of the S-layer proteins Sap and EA1 of Bacillus anthracis (Mesnage et al., 1999) and SlpA of Clostridium thermocellum (Lemaire et al., 1998; Chauvaux et al., 1999) comprising the three SLH motifs were able to attach to the rigid cell wall layer via a peptidoglycan-associated cell wall polymer.

As demonstrated in previous studies, a proteolytic cleavage fragment of the S-layer protein SbsC from $B$. stearothermophilus ATCC 12980 lacking the N-terminal 227 aa had lost the ability to bind to the native peptidoglycan-anionic polymer complex, but was still able to self-assemble (Egelseer $\mathrm{et} \mathrm{al.,} \mathrm{1998;} \mathrm{Jarosch} \mathrm{et} \mathrm{al.,}$ 2000). From affinity studies it became apparent that the $\mathrm{N}$-terminal part of SbsC recognizes the secondary cell wall polymer as the proper anchoring structure in the rigid cell wall layer. Studies on the biological function revealed that the oblique S-layer lattice from B. stearothermophilus ATCC 12980 serves as an adhesion site for HMMA, an exoamylase that was produced by the Slayer-carrying as well as by the S-layer-deficient strain (Egelseer et al., 1996). Several studies indicated that HMMA does not participate in the self-assembly process but recognizes protein domains that are exposed on the outer S-layer surface (Egelseer et al., 1996, 1997).

To obtain more insight into the structure-function relationship of distinct segments of the S-layer protein $\mathrm{SbsC}$, the PCR products encoding three $\mathrm{N}$ - or seven Cterminal truncations were cloned and expressed in $E$. coli HMS174(DE3). In agreement with the results obtained from previous studies (Egelseer et al., 1998; Jarosch et al., 2000) with the proteolytic cleavage fragment of the S-layer protein SbsC lacking the $\mathrm{N}$ terminal 227 aa, all $\mathrm{N}$-terminal truncations had lost the ability to bind to the native peptidoglycan-anionic polymer complex, while all C-terminal truncations recognized them as a binding site. Thus, it is obvious that the N-terminal region comprising aa $31-257$ is responsible for cell wall binding.

In contrast to $\mathrm{rSbsC}_{31-1099}$ and to the self-assembling Cterminal truncations which formed in vitro monolayers as well as double-layer self-assembly products, the $\mathrm{N}$ terminal truncation $\mathrm{rSbsC}_{258-1099}$ reassembled exclusively into monolayer cylinders exhibiting an oblique lattice structure (Fig. 3c). This observation indicated that the $\mathrm{N}$-terminal region of $\mathrm{Sbs} \mathrm{C}$ is responsible for double-layer formation, which was independent of the presence of bivalent cations. In a previous study, conditions leading to the formation of monolayer or double-layer self-assembly products, or both, were investigated in detail for the wild-type S-layer glycoprotein from B. stearothermophilus NRS 2004/3a (Messner et al., 1986). Interestingly, in double-layer selfassembly products the individual monolayers had bound to each other with the inner S-layer surface. Doublelayer formation occurred only in the presence of bivalent cations. Because polycationized ferritin was densely bound by the monolayer self-assembly products, but not at all by the double layers, it was concluded that the inner S-layer surface has a net negative charge. These findings are in clear contrast to the results obtained in the present study for the self-assembly products consisting of $\mathrm{rSbsC}_{31-1099}$, since on the one hand, the monolayers did not bind polycationized ferritin, while on the other hand, the formation of double-layer selfassembly products was independent of the presence of bivalent cations. Moreover, sequence analysis revealed that the N-terminal part of SbsC which must be located on the inner S-layer surface and is conserved among $\mathrm{S}$ layer proteins from B. stearothermophilus wild-type strains (Sára \& Sleytr, 2000) reveals a positive net charge with a $\mathrm{pI}>9$. These data strongly indicate that the net negative charge determined on the inner S-layer surface of self-assembly products formed by the wild-type Slayer proteins might result from adherent secondary cell wall polymer (Egelseer et al., 1998; Sára et al., 1998; Sára \& Sleytr, 2000).

Affinity studies with the HMMA and self-assembly products formed by $\mathrm{rSbsC}_{31-1099}, \mathrm{rSbsC}_{258-1099}$ or $\mathrm{rSbsC}_{31-880}$ demonstrated that the exoenzyme requires the $\mathrm{N}$-terminal part for binding to this S-layer protein. Comparison of the $\mathrm{N}$-terminal part of $\mathrm{SbsC}$ with the amylase-binding protein AbpA from Streptococcus gordonii (Rogers et al., 1998) revealed the existence of common sequences comprising 6 aa (AKAALD) and 7 aa (KAAYEAA). In SbsC, the 7 aa sequence is located in the N-terminal part between aa 254 and 260, and carries a glutamic acid residue which is attacked by endoproteinase Glu-C and can therefore be expected to be exposed on the surface of the S-layer subunits (Egelseer et al., 1998). Derived from secondary-structure prediction, the $\mathrm{N}$-terminal part is mainly organized as $\alpha$ helices connected by loops and seems to fold independently of the remainder of the protein sequence. Although the N-terminal part is involved in cell wall binding and a major portion must therefore be located on the inner S-layer surface, it cannot be excluded that certain sequences are exposed on the outer S-layer surface, thereby functioning as adhesion site for HMMA. It was interesting to observe that the 6 and 7 aa sequences which were identical to those on AbpA of S. gordonii (Rogers et al., 1998) were located at the end of the N-terminal part, which connects this structurally defined domain to that part of the sequence responsible for the formation of the oblique lattice structure. In contrast to the S-layer protein, HMMA could bind to peptidoglycan of the A $1 \gamma$-chemotype, but it is not currently known whether the exoenzyme also shows affinity to the secondary cell wall polymer. The pullulanase of Thermoanaerobacterium thermosulfurigenes EM1 was demonstrated to bind via its SLH motifs to the native peptidoglycan-anionic polymer complex. However, a reduced amount of this exoenzyme was able to attach to the HF-extracted peptidoglycananionic polymer complex, which most probably represented pure peptidoglycan (Brechtel \& Bahl, 1999). Surface plasmon resonance, a method to determine molecular interactions, further revealed that HMMA immobilized on the sensor chips could bind the native peptidoglycan-anionic polymer complex as well as the 


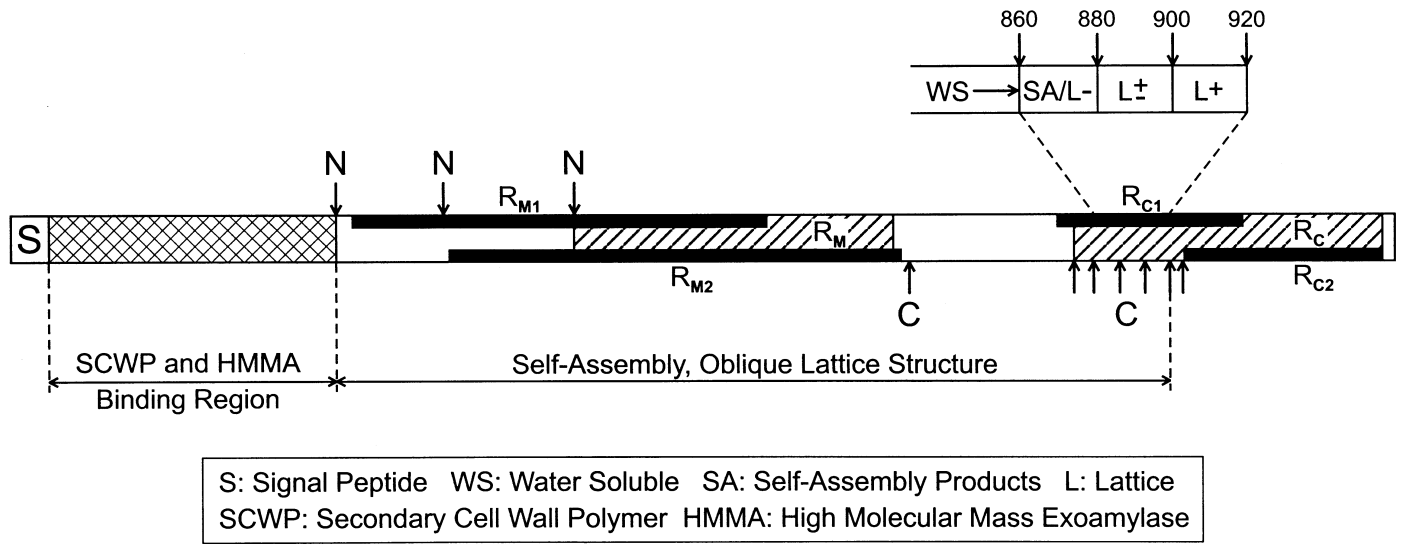

Fig. 7. Schematic drawing of the S-layer protein SbsC according to Jarosch et al. (2000). Arrows indicate the beginning of $\mathrm{N}$-terminal truncations $(\mathrm{N})$ and the end of C-terminal truncations (C). All N-terminal truncations stopped with aa 1099; all C-terminal truncations started with aa 31. The S-layer protein SbsC consists of several repeats: $R_{M}($ aa $447-700), R_{C}$ (844-1089), $23 \%$ identity; $R_{M 1}$ (aa 271-600), $R_{M 2}$ (aa 348-706), $23 \%$ identity; $R_{C 1}$ (aa 831-978), $R_{C 2}($ aa 931-1089), 28\% identity.

peptidoglycan, but the exoenzyme was not able to interact with non-assembled monomeric $\mathrm{rSbsC}_{31-1099}$ (unpublished results). These findings strongly indicated that in addition to appropriate HMMA-binding sites on the S-layer subunits, the oblique lattice structure or at least the dimers are required for exoenzyme binding. This is in agreement with observations on whole cells of B. stearothermophlius ATCC 12980 (Egelseer et al., 1996).

As described for the S-layer proteins of A. hydrophila and C. glutamicum (Thomas et al., 1992; Chami et al., 1997), the C-terminal part of SbsC is of major importance for the self-assembly process and for the formation of the oblique lattice structure. With the various C-terminal SbsC truncations it could be demonstrated that the C-terminal 219 aa do not determine the shape of the self-assembly products and can be deleted without interfering with the self-assembly process, while the C-terminal 179 aa are not required for the formation of the oblique lattice structure (Fig. 7).

In contrast to Sap of B. anthracis (Etienne-Toumelin et al., 1995) and CTC of Bacillus thuringiensis (M. Sun \& Z. Yu, GenBank accession no. AJ012290), SbsC possesses a longer N-terminal part and no SLH motifs, as well as a longer C-terminal part. From sequence comparison it was suggested that the additional Cterminal amino acids on the $\mathrm{SbsC}$ sequence (beyond aa $880)$ are not required for the self-assembly of this S-layer protein (Jarosch et al., 2000), which could actually be confirmed by experimental data in the present study with the various $\mathrm{C}$-terminal truncations.

\section{ACKNOWLEDGEMENTS}

This work was supported by the Austrian Science Foundation, project P12938, and by the Ministry of Science and Transport. We thank Christoph Hotzy and Aida Medovic for excellent technical assistance.

\section{REFERENCES}

Archibald, A. R., Hancock, I. C. \& Harwood, C. R. (1993). Cell wall structure, synthesis, and turnover. In Bacillus subtilis and Other Gram-Positive Bacteria, pp. 381-410. Edited by A. Sonenshein, J. A. Hoch \& R. Losick. New York: Academic Press.

Brechtel, E. \& Bahl, H. (1999). In Thermoanaerobacterium thermosulfurigenes EM1 S-layer homology domains do not attach to peptidoglycan. J Bacteriol 181, 5017-5023.

Chami, M., Bayan, N., Peyret., J. L., Gulik-Krzywicki, T., Leblon, G. \& Shechter, E. (1997). The S-layer protein of Corynebacterium glutamicum is anchored to the cell wall by its C-terminal hydrophobic domain. Mol Microbiol 23, 483-492.

Chauvaux, S., Matuschek, M. \& Béguin, P. (1999). Distinct affinity of binding sites for S-layer homologous domains in Clostridium thermocellum and Bacillus anthracis. J Bacteriol 181, 2455-2458.

Egelseer, E. M., Schocher, I., Sleytr, U. B. \& Sára, M. (1996). Evidence that an $\mathrm{N}$-terminal S-layer protein fragment triggers the release of a cell wall-associated high-molecular weight amylase from Bacillus stearothermophilus ATCC 12980. J Bacteriol 178, 5602-5609.

Egelseer, E. M., Schocher, I., Sleytr, U. B. \& Sára, M. (1997). Evidence that the S-layer of Bacillus stearothermophilus strains functions as an adhesion site for a high-molecular mass amylase. FEMS Microbiol Rev 20, 114-118.

Egelseer, E. M., Leitner, K., Jarosch, M., Hotzy, C., Zayni, S., Sleytr, U. B. \& Sára, M. (1998). The S-layer proteins of two Bacillus stearothermophilus wild-type strains are bound via their $\mathrm{N}$-terminal region to a secondary cell wall polymer of identical chemical composition. J Bacteriol 180, 1488-1495.

Etienne-Toumelin, I., Sirard, J.-C., Duflot, E., Mock, M. \& Fouet, A. (1995). Characterization of the Bacillus anthracis S-layer: cloning and sequencing of the structural gene. J Bacteriol 177, 614-620.

Ilk, N., Kosma, P., Puchberger, M., Egelseer, E. M., Mayer, H. F., Sleytr, U. B. \& Sára, M. (1999). Complete structural analysis and biological function of the secondary cell wall polymer of Bacillus sphaericus CCM 2177 serving as an S-layer specific anchor. J Bacteriol 181, 7643-7646.

Jarosch, M., Egelseer, E. M., Mattanovich, D., Sleytr, U. B. \& Sára, M. (2000). S-layer gene sbsC of Bacillus stearothermophilus 
ATCC 12980: molecular characterization and heterologous expression in Escherichia coli. Microbiology 146, 273-281.

Lacks, S. A. \& Springhorn, S. S. (1980). Renaturation of enyzmes after polyacrylamide gel electrophoresis in the presence of sodium dodecyl sulfate. J Biol Chem 255, 7467-7473.

Laemmli, U. K. (1970). Cleavage of structural proteins during the assembly of the head of bacteriophage T4. Nature 227, 680-685.

Lemaire, M., Miras, I., Gounon, P. \& Béguin, P. (1998). Identification of a region responsible for binding to the cell wall within the S-layer protein of Clostridium thermocellum. Microbiology 144, 211-217.

Mesnage, S., Tosi-Couture, E. \& Fouet, A. (1999). Production and cell surface anchoring of functional fusions between the SLH motifs of the Bacillus anthracis S-layer proteins and the Bacillus subtilis levansucrase. Mol Microbiol 31, 927-936.

Messner, P., Hollaus, F. \& Sleytr, U. B. (1984). Paracrystalline cell wall surface layers of different Bacillus stearothermophilus strains. Int J Syst Bacteriol 34, 202-210.

Messner, P., Pum, D. \& Sleytr, U. B. (1986). Characterization of the ultrastructure and the self-assembly of the surface layer of Bacillus stearothermophilus strain NRS 2004/3a. J Ultrastuct Mol Struct Res 97, 73-88.

Olabarría, G., Carrascosa, J. L., De Pedro, M. A. \& Berenguer, J. (1996). A conserved motif in S-layer proteins is involved in peptidoglycan binding in Thermus thermophilus. J Bacteriol 178, 4765-4772.

Ries, W., Hotzy, C., Schocher, I., Sleytr, U. B. \& Sára, M. (1997). Evidence that the $\mathrm{N}$-terminal part of the S-layer protein from Bacillus stearothermophilus PV72/p2 recognizes a secondary cell wall polymer. J Bacteriol 179, 3892-3898.

Rogers, J. D., Haase, E. M., Brown, A. E., Douglas, C. W. I., Gwynn, J. P. \& Scannapieco, F. A. (1998). Identification and analysis of a gene $(a b p A)$ encoding a major amylase-binding protein in Streptococcus gordonii. Microbiology 144, 1223-1233.

Sambrook, J., Fritsch, E. F. \& Maniatis, T. (1989). Molecular Cloning: a Laboratory Manual, 2nd edn. Cold Spring Harbor, NY: Cold Spring Harbor Laboratory.

Sára, M. \& Sleytr, U. B. (2000). S-layer proteins. J Bacteriol 182, 859-868.

Sára, M., Kuen, B., Mayer, H. F., Mandl, F., Schuster, K. C. \& Sleytr,
U. B. (1996). Dynamics in oxygen-induced changes in S-layer protein synthesis from Bacillus stearothermophilus PV72 and its S-layer deficient variant T5 in continuous culture and studies on the cell wall composition. J Bacteriol 178, 2108-2117.

Sára, M., Dekitsch, C., Mayer, H. F., Egelseer, E. M. \& Sleytr, U. B. (1998). Influence of the secondary cell wall polymer on the reassembly, recrystallization and stability properties of the Slayer protein from Bacillus stearothermophilus PV72/p2. J Bacteriol 180, 4146-4153.

Schäffer, C., Kählig, H., Christian, R., Schulz, G., Zayni, S. \& Messner, P. (1999). The diacetamidodideoxyuronic acid-containing glycan chain of Bacillus stearothermophilus NRS 2004/3a represents the secondary cell wall polymer of wild-type $B$. stearothermophilus strains. Microbiology 145, 1575-1583.

Sleytr, U. B. \& Beveridge, T. J. (1999). Bacterial S-layers. Trends Microbiol 7, 253-260.

Sleytr, U. B., Messner, P., Pum, D. \& Sára, M. (1999). Crystalline bacterial cell surface layers (S-layers): from cell structure to biomimetics and nanotechnology. Angew Chem Int Ed Engl 38, 1034-1054.

Studier, F. W., Rosenberg, A. H., Dunn, J. J. \& Dubendorff, J. W. (1990). Use of T7 RNA polymerase to direct expression of cloned genes. Methods Enzymol 185, 60-89.

Thomas, S., Austin, J. W., McCubbin, W. D., Kay, C. M. \& Trust, T. J. (1992). Roles of structural domains in the morphology and surface anchoring of the tetragonal paracrystalline array of Aeromonas hydrophila. J Mol Biol 228, 652-661.

Transue, T. R., Smith, K. A., Mo, H., Goldstein, I. J. \& Saper, M. A. (1997). Structure of benzyl-T-antigen disaccharide bound to Amaranthus caudatus agglutinin. Nature Struct Biol 4, 779-783.

Trust, T. J. (1993). Molecular, structural and functional properties of Aeromonas S-layers. In Advances in Bacterial Paracrystalline Surface Layers, pp. 159-173. Edited by T. J. Beveridge \& S. F. Koval. New York: Plenum.

Weis, W. I. (1997). Cell-surface carbohydrate recognition by animal and viral lectins. Curr Opin Struct Biol 7, 624-630.

Received 29 September 2000; revised 8 January 2001; accepted 30 January 2001. 